Nevada

Environmental

Restoration

Project

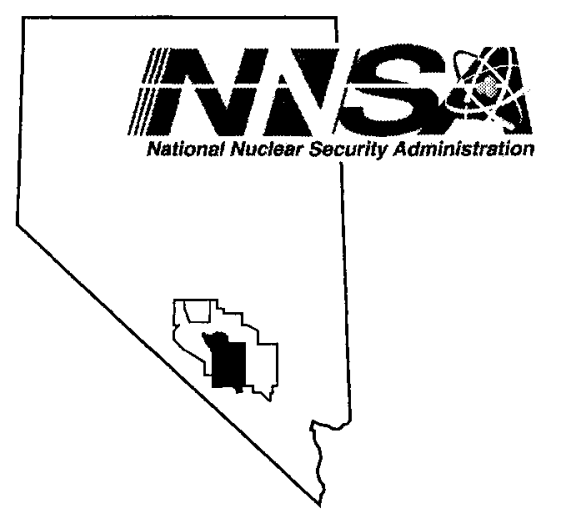

\title{
Corrective Action Plan for Corrective Action Unit 214: Bunkers and Storage Areas, Nevada Test Site, Nevada
}

Controlled Copy No.:

Revision: 0

March 2005

\section{Environmental Restoration}

Division 


\section{DISCLAIMER}

Reference herein to any specific commercial product, process, or service by trade name, trademark, manufacturer, or otherwise, does not necessarily constitute or imply its endorsement, recommendation, or favoring by the U.S. Government or any agency thereof or its contractors or subcontractors.

This report has been reproduced directly from the best available copy.

Available for sale to the public from:

U.S. Department of Commerce

National Technical Information Service

5285 Port Royal Road

Springfield, VA 22161-0002

Telephone: (800) 553-6847

Fax: (703) 605-6900

E-mail: orders@ntis.gov

Online ordering: http:/www.ntis.gov/ordering.htm

Available electronically at http://www.osti.gov/bridge.

Available for a processing fee to the U.S. Department of Energy and its contractors, in paper, from:

U.S. Department of Energy

Office of Scientific and Technical Information

P.O. Box 62

Oak Ridge, TN 37831-0062

Telephone: (865) 576-8401

Fax: (865) 576-5728

E-mail: reports@adonis.osti.gov 


\title{
CORRECTIVE ACTION PLAN FOR CORRECTIVE ACTION UNIT 214: BUNKERS AND STORAGE AREAS, NEVADA TEST SITE, NEVADA
}

\author{
Prepared for: \\ U.S. Department of Energy \\ National Nuclear Security Administration \\ Nevada Site Office \\ Under Contract No. DE-AC08-96NV11718
}

Controlled Copy No.

Revision: 0

March 2005 
THIS PAGE INTENTIONALLY LEFT BLANK 


\section{CORRECTIVE ACTION PLAN FOR CORRECTIVE ACTION UNIT 214: BUNKERS AND STORAGE AREAS, NEVADA TEST SITE, NEVADA}

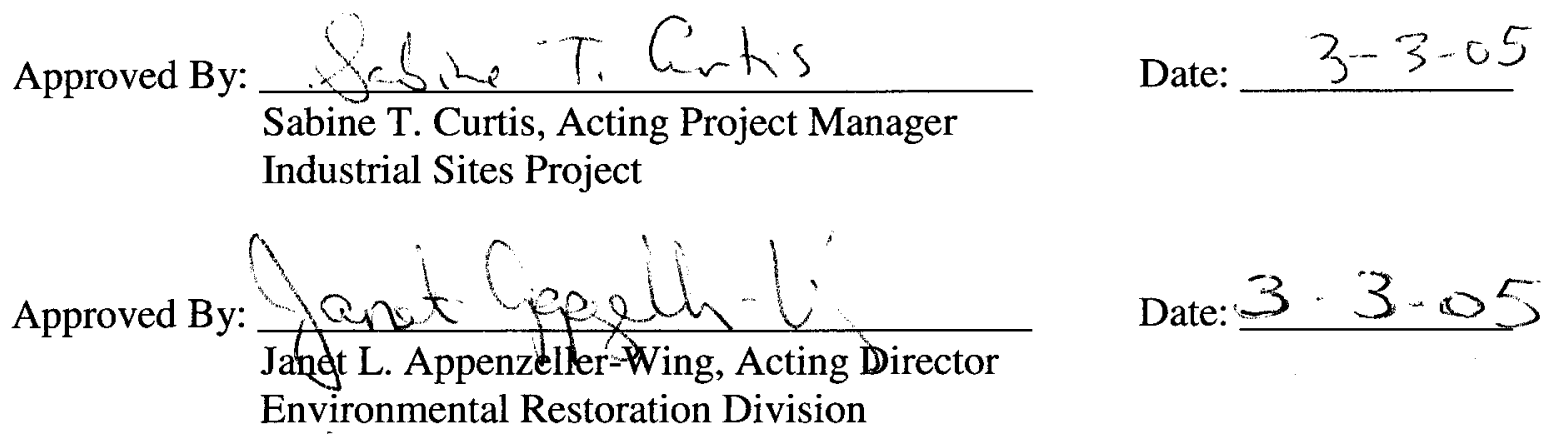


THIS PAGE INTENTIONALLY LEFT BLANK 


\section{TABLE OF CONTENTS}

ACRONYMS AND ABBREVIATIONS …............................................................................ vii

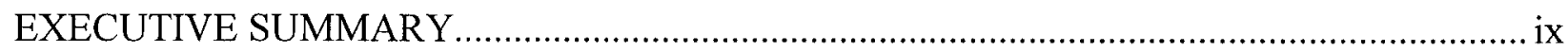

$1.0 \quad$ INTRODUCTION

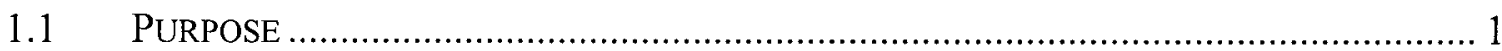

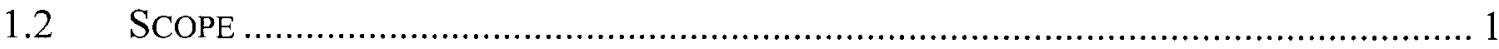

1.3 CAP CONTENTS ......................................................................................... 3

2.0 DETAILED SCOPE OF WORK

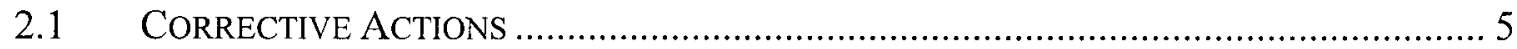

2.1.1 Alternative 1 - No Further Action.......................................................... 5

2.1.1.1 CAS 11-22-03, Drum.......................................................... 5

2.1.1.2 CASs 25-34-03, 25-34-04, and 25-34-05, Motor Dr/Gr Assembly

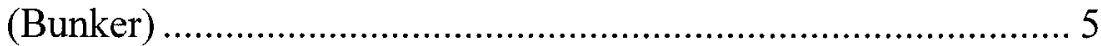

2.1.1.3 CAS 25-99-12, Fly Ash Storage ............................................ 10

2.1.1.4 CAS 25-99-18, Storage Area .................................................. 10

2.1.2 Alternative 2 - Clean Closure …………........................................... 10

2.1.2.1 CAS 05-99-01, Fallout Shelters ................................................ 10

2.1.3 Alternative 3 - Close in Place with Administrative Controls ................... 15

2.1.3.1 CAS 25-23-01, Contaminated Materials, and CAS 25-23-19, Radioactive Material Storage................................................... 15

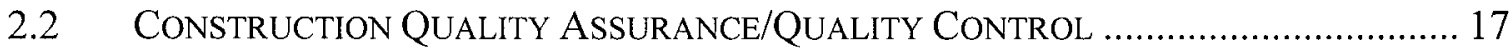

2.2.1 Construction Field Sample Collection Activities .................................... 17

2.2.2 Construction Laboratory/Analytical Data Quality Indicators ................... 17

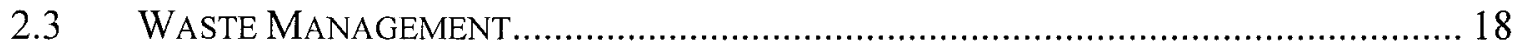

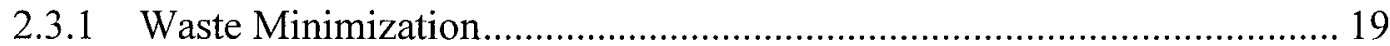

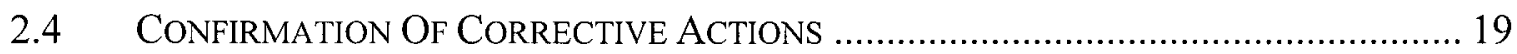

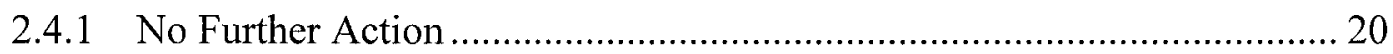

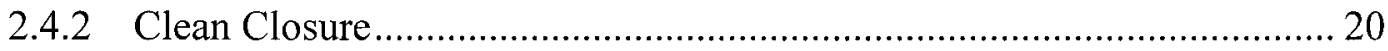

2.4.2.1 CAS 05-99-01, Fallout Shelters ............................................ 20

2.4.3 Closure in Place with Administrative Controls ....................................... 20

2.4.3.1 CAS 25-23-01, Contaminated Materials, and CAS 25-23-19, Radioactive Material Storage.................................................. 20

2.4.4 Laboratory/Analytical Data Quality Indicators ....................................... 21

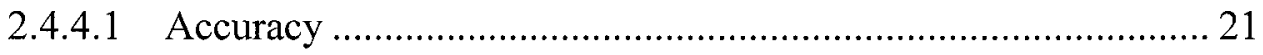

2.4.4.2 Comparability....................................................................... 21

2.4.4.3 Completeness ....................................................................... 21

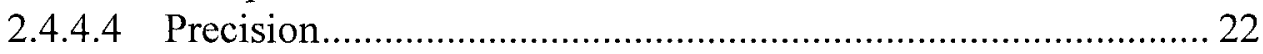

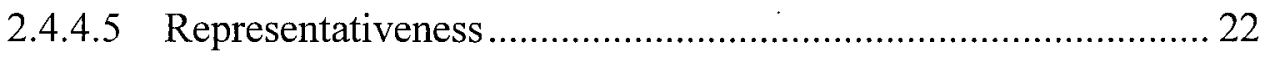

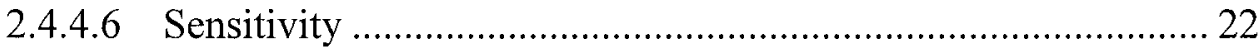

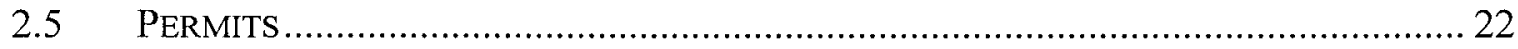

2.5.1 National Environmental Policy Act Checklist ......................................... 22

2.5.2 NNSA/NSO Real Estate/Operations Permit ............................................. 22

2.5.3 Radiological Work Permit ..................................................................... 22 


\section{TABLE OF CONTENTS (continued)}

2.5.4 Utility Clearances and Excavation Permits.............................................. 23

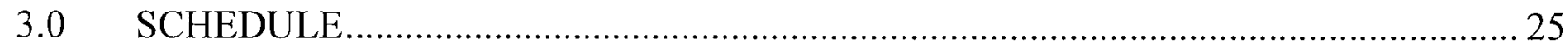

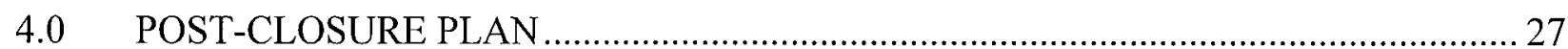

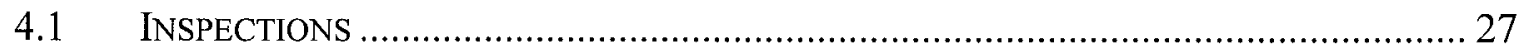

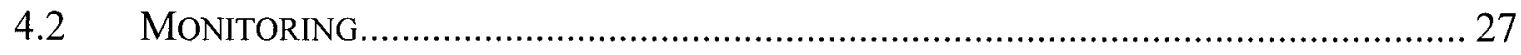

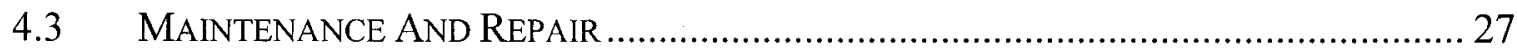

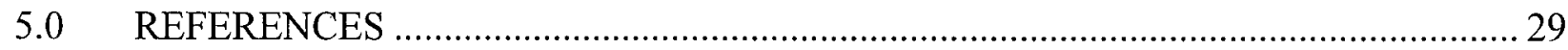

\section{FIGURES}

FIGURE 1. Location of the NTS and CAU 214, Bunkers and Storage Areas............................. 2

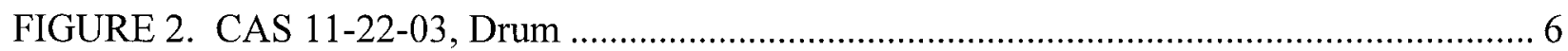

FIGURE 3. CAS 25-34-03, Motor Dr/Gr Assembly (Bunker) ……....................................... 7

FIGURE 4. CAS 25-34-04, Motor Dr/Gr Assembly (Bunker) …….......................................... 8

FIGURE 5. CAS 25-34-05, Motor Dr/Gr Assembly (Bunker) ……......................................... 9

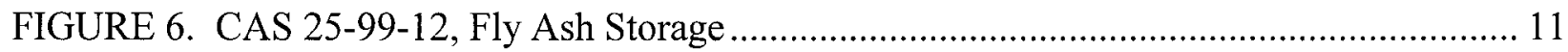

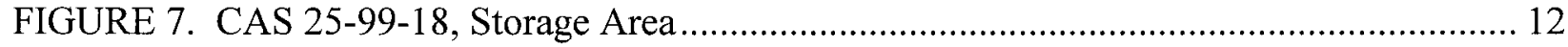

FIGURE 8. CAS 05-99-01, Fallout Shelters.......................................................................... 13

FIGURE 9. CAS 25-23-01, Contaminated Materials, and CAS 25-23-19, Radioactive Material Storage

\section{TABLES}

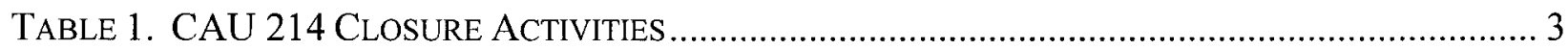

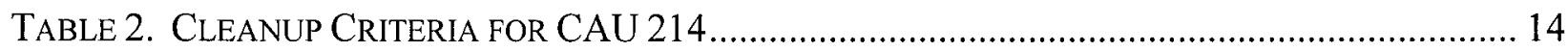

TABLE 3. ITEMS TO REMAIN AT CAS 25-23-01 ...................................................................... 17

\section{APPENDICES}

APPENDIX A.1 - ENGINEERING SPECIFICATIONS AND DRAWINGS

APPENDIX A.2 - SAMPLING AND ANALYSIS PLAN

APPENDIX A.3 - PROJECT ORGANIZATION

LIBRARY DISTRIBUTION LIST 


\section{ACRONYMS AND ABBREVIATIONS}

\begin{tabular}{|c|c|}
\hline bgs & below ground surface \\
\hline BMP & Best Management Practice \\
\hline $\mathrm{BN}$ & Bechtel Nevada \\
\hline BREN & Bare Reactor Experiment Nevada \\
\hline CADD & Corrective Action Decision Document \\
\hline CAIP & Corrective Action Investigation Plan \\
\hline CAP & Corrective Action Plan \\
\hline CAS & Corrective Action Site \\
\hline $\mathrm{CAU}$ & Corrective Action Unit \\
\hline $\mathrm{COC}$ & Contaminant of Concern \\
\hline CR & Closure Report \\
\hline DOE & U.S. Department of Energy \\
\hline $\mathrm{DOE} / \mathrm{NV}$ & U.S. Department of Energy, Nevada Operations Office \\
\hline DQI & Data Quality Indicator \\
\hline DQO & Data Quality Objective \\
\hline $\mathrm{Dr} / \mathrm{Gr}$ & Drive/Gear \\
\hline DRO & Diesel Range Organics \\
\hline EPA & U.S. Environmental Protection Agency \\
\hline ETS-1 & Engine Test Stand 1 \\
\hline FFACO & Federal Facility Agreement and Consent Order \\
\hline $\mathrm{ft}$ & foot (feet) \\
\hline FY & Fiscal Year \\
\hline $\mathrm{HW}$ & Hazardous waste \\
\hline LLW & Low-level waste \\
\hline$\mu \mathrm{g} / \mathrm{kg}$ & microgram(s) per kilogram \\
\hline $\mathrm{m}$ & meter(s) \\
\hline $\mathrm{m}^{3}$ & cubic meter(s) \\
\hline $\mathrm{mg} / \mathrm{kg}$ & milligram(s) per kilogram \\
\hline MW & Mixed waste \\
\hline MX & Missile Experiment \\
\hline
\end{tabular}




\section{ACRONYMS AND ABBREVIATIONS (continued)}

NAC

NDEP

NEPA

NNSA/NSO

NNSA/NV

NTS

OI

PAL

PPE

QA

QC

RCRA

REOP

RMA

RPD

RWP

SOW

TCLP

TPH

TSD

$\mathrm{yd}^{3}$

YMP-SMF
Nevada Administrative Code

Nevada Division of Environmental Protection

National Environmental Policy Act

U.S. Department of Energy, National Nuclear Security Administration Nevada Site Office

U.S. Department of Energy, National Nuclear Security Administration Nevada Operations Office

Nevada Test Site

Organization Instruction

Preliminary Action Level

Personal Protective Equipment

Quality Assurance

Quality Control

Resource Conservation and Recovery Act

Real Estate/Operations Permit

Radioactive Materials Area

Relative Percent Difference

Radiological Work Permit

Scope of Work

Toxicity Characterization Leaching Procedure

Total Petroleum Hydrocarbons

Treatment, storage, and disposal

cubic yard(s)

Yucca Mountain Project Sample Management Facility 


\section{EXECUTIVE SUMMARY}

Corrective Action Unit (CAU) 214, Bunkers and Storage Areas, is identified in the Federal Facility Agreement and Consent Order of 1996. CAU 214 consists of nine Corrective Action Sites (CASs) located in Areas 5, 11, and 25 of the Nevada Test Site (NTS). The NTS is located approximately 105 kilometers (65 miles) northwest of Las Vegas, Nevada, in Nye County.

CAU 214 was previously characterized in 2004, and results were presented in the Corrective Action Decision Document (CADD) for CAU 214 (U.S. Department of Energy, National Nuclear Security Administration Nevada Site Office [NNSA/NSO], 2004). Site characterization indicated that soil and/or debris exceeded clean-up criteria for Total Petroleum Hydrocarbons (TPH), pesticides, metals, and radiological contamination.

The Nevada Division of Environmental Protection approved the proposed corrective actions specified in the CADD (NNSA/NSO, 2004). The approved corrective actions include no further action, clean closure, and closure in place with administrative controls.

No further action will be implemented at the following CASs:

- CAS 11-22-03, Drum: The site consists of two 55-gallon steel drums containing solid debris and two metal cable piles located in a high contamination area. The debris is not contributing to soil contamination at the site. No further action will be taken due to the high risk to human health associated with entering the high contamination area to remove the debris.

- CASs 25-34-03, 25-34-04, and 25-24-05, Motor Dr/Gr Assembly (Bunker): No further action will be taken, as no contaminants of concern (COCs) are present.

- CAS 25-99-12, Fly Ash Storage: The site consists of fly ash within a deteriorating wooden structure. No contamination is present in the soil. The fly ash and wooden structure will be removed and disposed of as a best management practice (BMP).

- CAS 25-99-18, Storage Area: No COCs are present, and no further action will be taken.

Clean closure will be implemented at the following CAS:

- CAS 05-99-01, Fallout Shelters: The site consists of soil contaminated above the Preliminary Action Level with the pesticide dieldrin. The site will be clean closed by removing and disposing of the contaminated soil.

Closure in place with administrative controls will be implemented at the following CASs:

- CAS 25-23-01, Contaminated Materials: The site consists of surface soil contaminated with low concentrations of TPH. Administrative controls (i.e., use restrictions) will be implemented. Wood and metal debris scattered throughout the site will be removed and disposed of as a BMP.

- CAS 25-23-19, Radioactive Material Storage: The site consists of soil contaminated with chromium, pesticides (heptachlor and chlordane), and TPH. Low concentrations of TPH are present in surface soil throughout the site. The soil contaminated with chromium, pesticides, and high concentrations of TPH will be excavated and disposed of as a BMP. Administrative controls will be implemented for the area containing low concentrations of TPH contamination (less than 580 milligrams per kilogram). 


\subsection{INTRODUCTION}

Corrective Action Unit (CAU) 214, Bunkers and Storage Areas, is listed in the Federal Facility Agreement and Consent Order (FFACO, 1996). CAU 214 sites are located in Areas 5, 11, and 25 of the Nevada Test Site (NTS). The NTS is approximately 105 kilometers (65 miles) northwest of Las Vegas, Nevada (Figure 1). CAU 214 consists of the following nine Corrective Action Sites (CASs):

- CAS 05-99-01, Fallout Shelters

- CAS 11-22-03, Drum

- CAS 25-23-01, Contaminated Materials

- CAS 25-23-19, Radioactive Material Storage

- CAS 25-34-03, Motor Dr/Gr Assembly (Bunker)

- CAS 25-34-04, Motor Dr/Gr Assembly (Bunker)

- CAS 25-34-05, Motor Dr/Gr Assembly (Bunker)

- CAS 25-99-12, Fly Ash Storage

- $\quad$ CAS 25-99-18, Storage Area

\subsection{PURPOSE}

CAU 214 consists of nine CASs located in Areas 5, 11, and 25 of the NTS. Detailed information on the site history and results of characterization activities can be found in the Corrective Action Investigation Plan (CAIP) (U.S. Department of Energy, National Nuclear Security Administration Nevada Site Office [NNSA/NSO], 2003) and the Corrective Action Decision Document (CADD) (NNSA/NSO, 2004). The CAIP describes the site history, outlines a site characterization plan, and proposes Preliminary Action Levels (PALs) to evaluate the need for possible corrective actions. Site characterization activities were performed in 2004 , and the results are reported in Appendix A of the CADD. The CADD also proposes appropriate corrective actions for each CAS.

This Corrective Action Plan (CAP) presents the detailed scope of work (SOW) required to accomplish the closure activities specified in the CADD for CAU 214 (NNSA/NSO, 2004).

\subsection{SCOPE}

The approved closure activities for CAU 214 include no further action, closure in place with administrative controls, and clean closure by excavation of impacted soil and removal of debris. Table 1 summarizes the CAS-specific closure activities and contaminants of concern (COCs) reported in the CADD (NNSA/NSO, 2004). Specific details of the corrective actions to be performed at each CAS are presented in Section 2.0, Detailed SOW. 


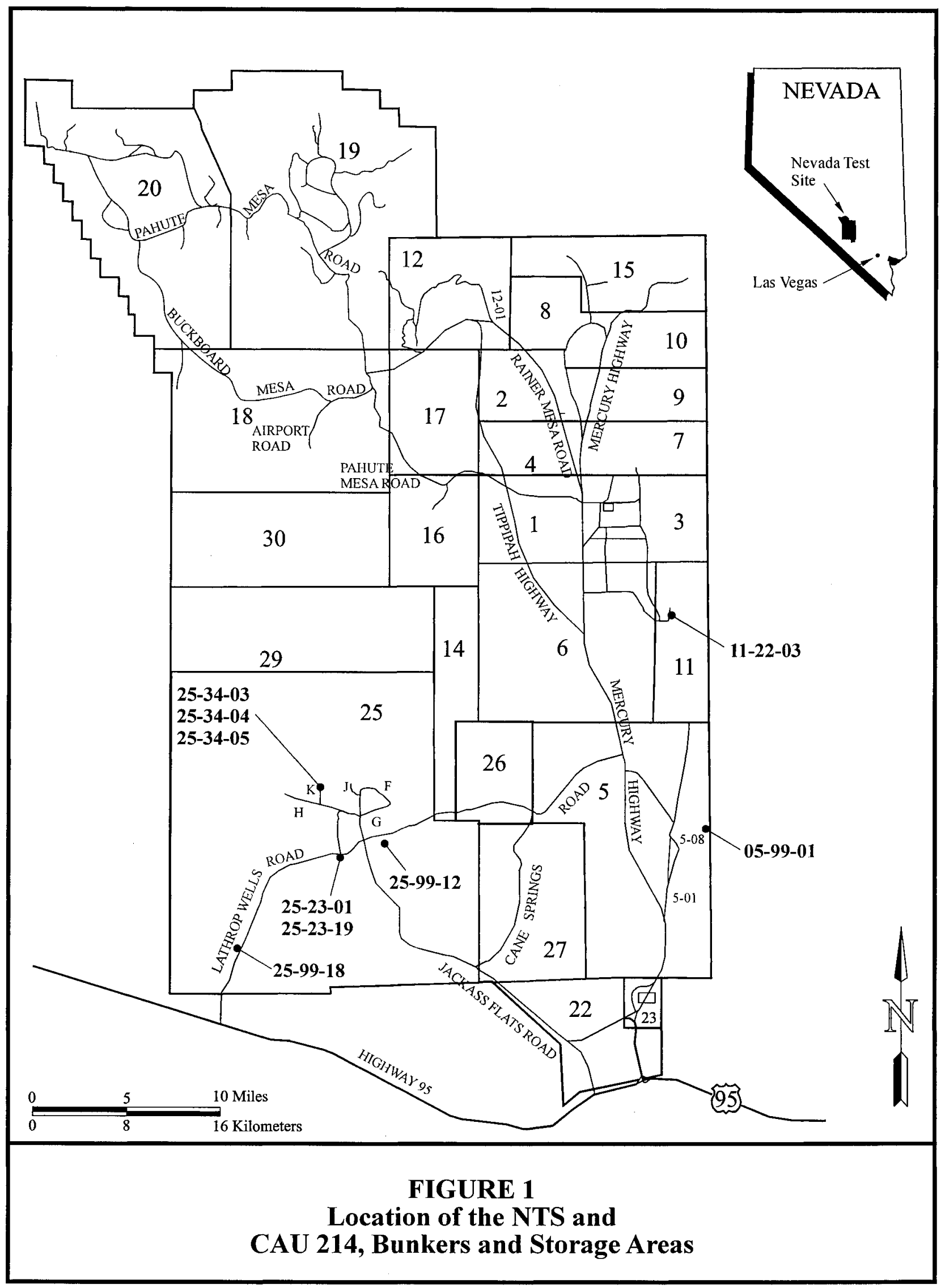


Table 1. CAU 214 Closure ACtivities

\begin{tabular}{|c|c|c|c|c|}
\hline CAS & NAME & $\begin{array}{l}\text { ClOSURE } \\
\text { METHOD } \\
\end{array}$ & COCs & SCOPE OF WORK \\
\hline $05-99-01$ & Fallout Shelters & $\begin{array}{l}\text { Clean } \\
\text { Closure }\end{array}$ & Dieldrin (pesticide) & $\begin{array}{l}\text { - Excavate and dispose of } \\
\text { contaminated soil. }\end{array}$ \\
\hline $11-22-03$ & Drum & $\begin{array}{l}\text { No Further } \\
\text { Action }\end{array}$ & $\begin{array}{l}\text { Radiological } \\
\text { Contamination }\end{array}$ & - None \\
\hline $25-23-01$ & Contaminated Materials & $\begin{array}{l}\text { Closure in } \\
\text { Place }\end{array}$ & TPH & $\begin{array}{l}\text { - Implement administrative controls. } \\
\text { - Remove wood and metal debris. }\end{array}$ \\
\hline $25-23-19$ & $\begin{array}{l}\text { Radioactive Material } \\
\text { Storage }\end{array}$ & $\begin{array}{l}\text { Closure in } \\
\text { Place }\end{array}$ & $\begin{array}{l}\text { TPH; chromium; and } \\
\text { heptachlor and } \\
\text { chlordane (pesticides) }\end{array}$ & $\begin{array}{l}\text { - Remove soil contaminated with } \\
\text { pesticides, chromium, and high } \\
\text { concentrations of TPH. } \\
\text { - Implement administrative controls for } \\
\text { low concentrations of TPH. }\end{array}$ \\
\hline $25-34-03$ & $\begin{array}{l}\text { Motor Dr/Gr Assembly } \\
\text { (Bunker) }\end{array}$ & $\begin{array}{l}\text { No Further } \\
\text { Action }\end{array}$ & None & - None \\
\hline $25-34-04$ & $\begin{array}{l}\text { Motor Dr/Gr Assembly } \\
\text { (Bunker) }\end{array}$ & $\begin{array}{l}\text { No Further } \\
\text { Action }\end{array}$ & None & - None \\
\hline $25-34-05$ & $\begin{array}{l}\text { Motor Dr/Gr Assembly } \\
\text { (Bunker) }\end{array}$ & $\begin{array}{l}\text { No Further } \\
\text { Action }\end{array}$ & None & - None \\
\hline $25-99-12$ & Fly Ash Storage & $\begin{array}{l}\text { No Further } \\
\text { Action }\end{array}$ & None & $\begin{array}{l}\text { - Remove fly ash and wooden storage } \\
\text { structure. }\end{array}$ \\
\hline $25-99-18$ & Storage Area & $\begin{array}{l}\text { No Further } \\
\text { Action }\end{array}$ & None & - None \\
\hline
\end{tabular}

Note: All sites in Area 25 are considered to potentially be impacted with Beryllium and Silica.

Dr/Gr: Drive/Gear

TPH: Total Petroleum Hydrocarbons

$\mathrm{mg} / \mathrm{kg}$ : milligrams per kilogram

\subsection{CAP CONTENTS}

This CAP is comprised of the following sections:

- Section 1.0 - Introduction

- Section 2.0 - Detailed Statement of Work

- Section 3.0 - Schedule

- Section 4.0 - Post-Closure Plan

- Section 5.0 - References

The appendices included in this document are as follows:

- Appendix A.1 - Engineering Specifications and Drawings

- Appendix A.2 - Sampling and Analysis Plan

- Appendix A.3 - Project Organization

- Library Distribution List 
Appendix A.1 is included as required by the approved FFACO outline but does not contain any material because engineering specifications and drawings are not required for closure.

Appendix A.2 is included as required by the approved FFACO outline but does not contain any material. Sufficient detail on the type, number, and location of verification samples to be collected to verify site closure activities has been provided in Section 2.4, Confirmation of Corrective Actions. Waste characterization sampling activities are described in Section 2.3, Waste Management.

This report was developed using information and guidance from the following documents:

- $\quad$ FFACO, 1996

- CAU 214 CAIP (NNSA/NSO, 2003)

- $\quad$ CAU 214 CADD (NNSA/NSO, 2004) 


\subsection{CORRECTIVE ACTIONS}

The corrective action alternatives for each CAS in CAU 214 were identified in the CADD (NNSA/NSO, 2004) and approved by the Nevada Division of Environmental Protection (NDEP). The approved alternatives include no further action, clean closure, and closure in place with administrative controls. The objective of the corrective action alternatives is to prevent or mitigate adverse environmental impacts due to exposure and migration of surface and subsurface waste. The tasks to be completed for each CAS are presented in the following sections.

\subsubsection{Alternative 1 - No Further Action}

\subsubsection{CAS 11-22-03, Drum}

This site, located in Plutonium Valley in Area 11, consists of two 55-gallon steel drums and two piles of metal cable in a fenced area labeled "Danger High Contamination Area" (Figure 2). Four nuclear safety experiments were conducted in 1955 and 1956 in this area. The origin of the drums and cables is unknown. One drum contains an air filter in a sealed plastic bag, and the other drum contains miscellaneous solid debris. It was determined that the drums, cables, and debris are not contributing contamination to the soil. Radionuclides found at this site are consistent with historical soil sampling conducted in Area 11 and are determined to originate from the safety experiments conducted in the area. Radioactive contamination resulting from the safety experiments and atmospheric nuclear testing is not considered part of this CAS and will be addressed during the Soils Project as specified in the CAU 214 CAIP (NNSA/NSO, 2003).

Due to the high risk to human health associated with entering the high contamination area to remove the drums and metal cables, no further action will be taken at this site. Since soil contaminated with radioactive fallout due to weapons testing is not a part of this CAS, no action will be taken to remove it at this time.

\subsubsection{CASs 25-34-03, 25-34-04, and 25-34-05, Motor Dr/Gr Assembly (Bunker)}

These sites are located at the Engine Test Stand 1 (ETS-1) in Area 25 (Figure 3, Figure 4, and Figure 5). The ETS-1 facility supported the testing of nuclear engines as part of the Nuclear Rocket Development Station. The bunkers were used from 1966 to 1970 to house cable spools and motor drive/gear (Dr/Gr) assemblies, which were to raise and lower an engine exhaust downhole cover and two radiation shields. A steel cable runs from each of the bunkers to the ETS-1. Each bunker is approximately 4.3 meters $(\mathrm{m})$ (14 feet [ft]) long by $2.4 \mathrm{~m}(8 \mathrm{ft})$ wide by $1.5 \mathrm{~m}(5 \mathrm{ft})$ tall, is constructed of reinforced concrete, and has an open roof. Rainwater is believed to have drained out through openings in the rear wall of each bunker. Small pieces of asphalt littering the area indicate that the area was at one time stabilized with a thin layer of asphalt.

Soil samples collected at CASs 25-34-03 and 25-34-04 indicate that Total Petroleum Hydrocarbons (TPH) Diesel Range Organics (DRO) is present above the PAL of 100 milligrams per kilogram (mg/kg); however, the TPH is attributed to the presence of asphalt in the surrounding area. Because asphalt is not considered an environmental contaminant, the TPH found at this site is not considered a COC, and no further action is required (NNSA/NSO, 2004). 


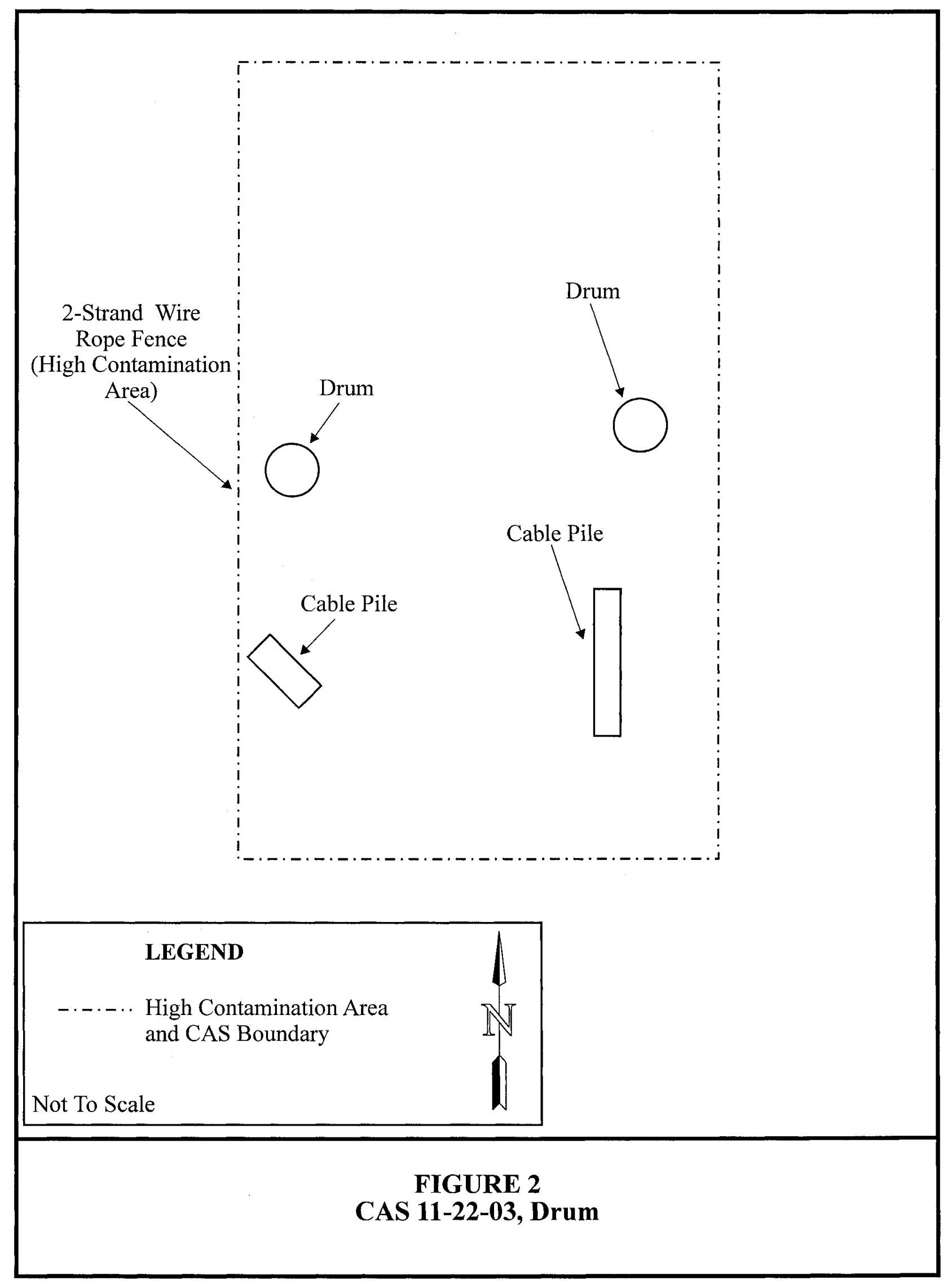




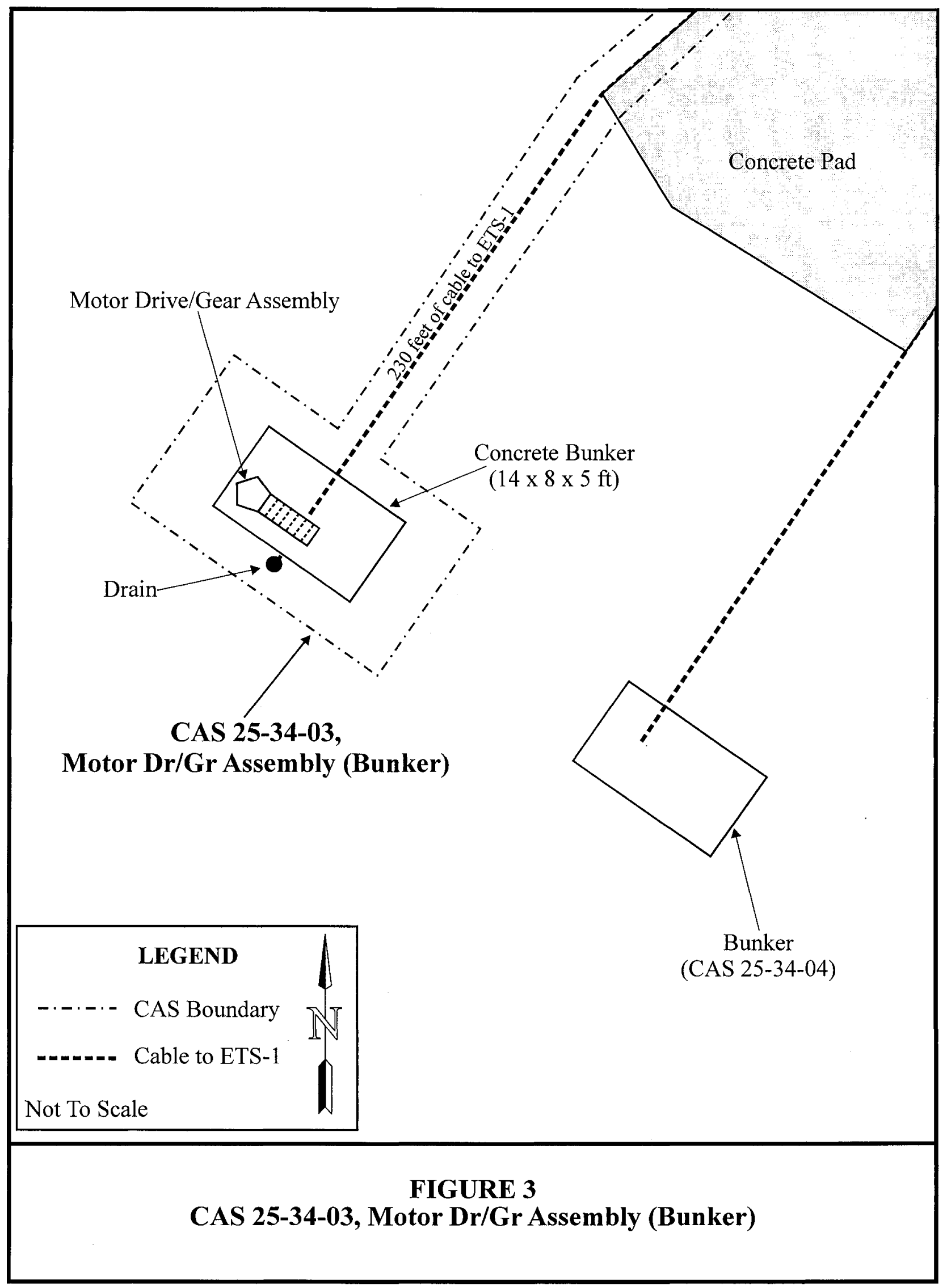




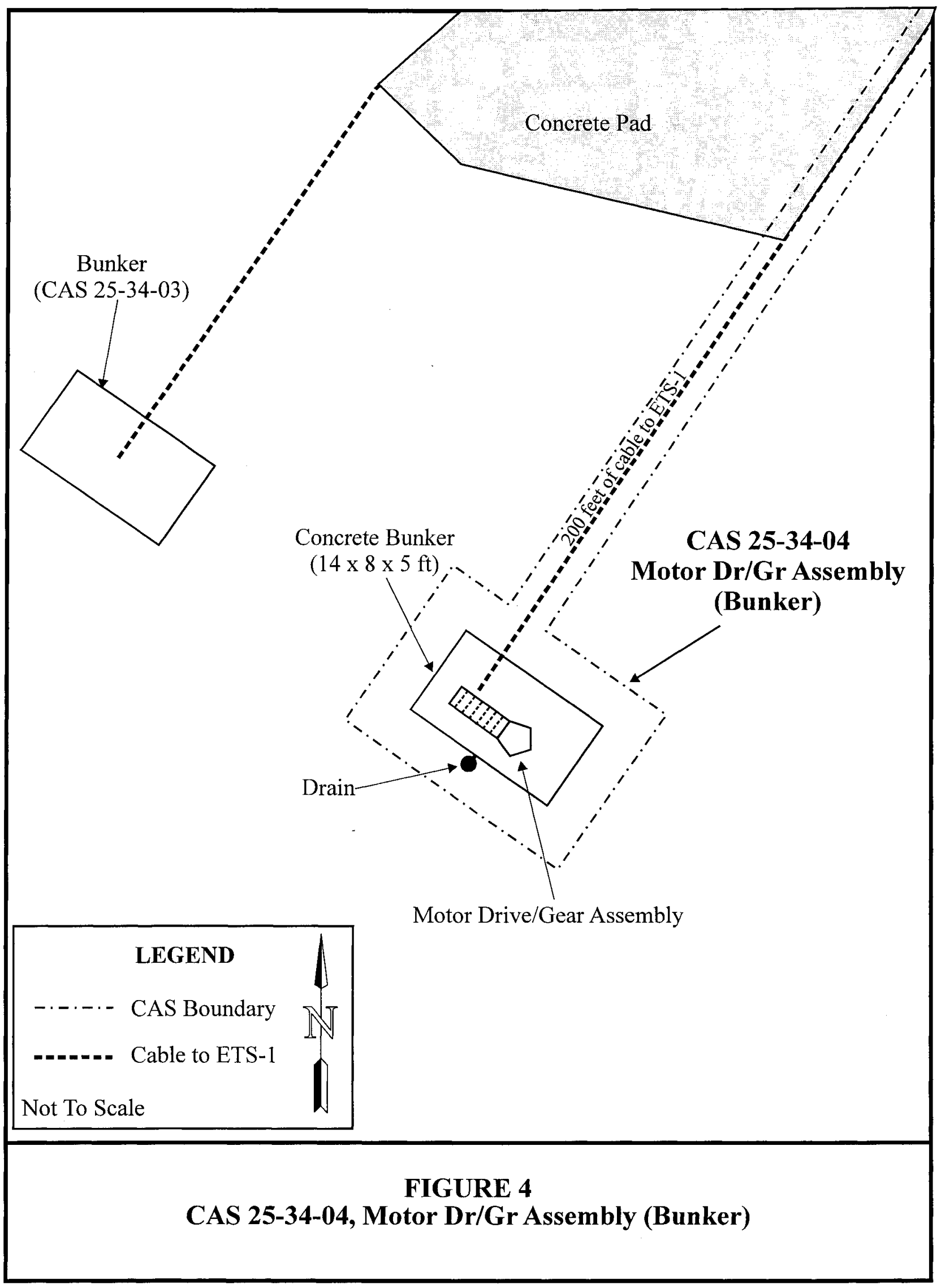




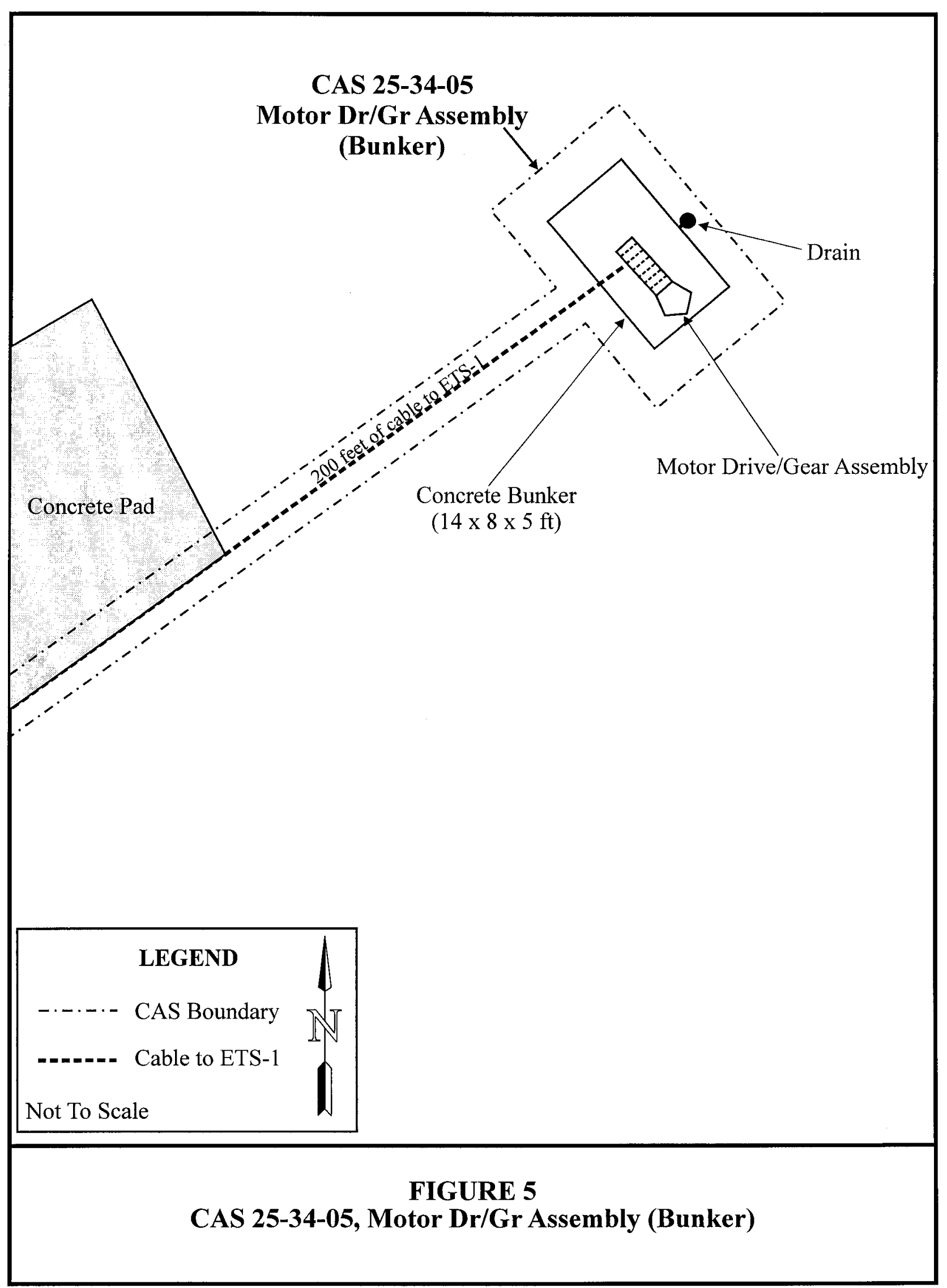




\subsubsection{CAS 25-99-12, Fly Ash Storage}

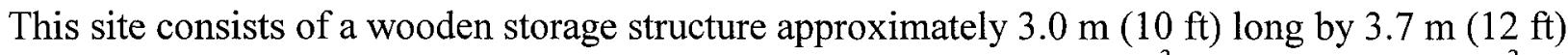
wide by $2.4 \mathrm{~m}(8 \mathrm{ft})$ tall containing approximately 11.5 cubic meters $\left(\mathrm{m}^{3}\right)\left(15\right.$ cubic yards $\left.\left[\mathrm{yd}^{3}\right]\right)$ of fly ash. The site is located approximately $152 \mathrm{~m}(500 \mathrm{ft})$ from the Bare Reactor Experiment Nevada (BREN) Tower in Area 25 (Figure 6). The fly ash storage building is in poor condition, and it is prevented from collapsing only by the presence of steel bands around the exterior walls.

The storage structure is adjacent to and west of a wooden one-story building with oriental-style architecture reportedly moved to the site from a mock Japanese Village in Area 4. The exact use of either building is unknown, although they may have been used in various experiments at the BREN Tower. The source of the fly ash is also unknown. Steel trusses are located to the west of the fly ash storage shed; however, they are not considered part of this CAS.

The fly ash does not contain COCs; therefore, no further action is required. However, as a best management practice, the fly ash will be removed and disposed of as sanitary waste at the NTS. The wooden storage structure will be demolished, and any associated construction debris at the site will be removed and disposed of as sanitary waste.

\subsubsection{CAS 25-99-18, Storage Area}

This site is located west of the Missile Experiment (MX) Missile Silos on Lanthrop Wells Road in Area 25 (Figure 7). The site was built between 1982 and 1983 and used to store heavy equipment and materials used during the MX Program. The site later became the storage yard for materials and scrap planned for sale as salvage. Much of the material was removed in 1996; however, three

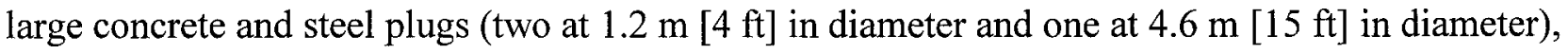

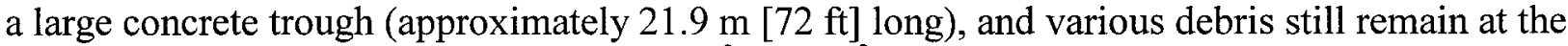
site. A lead brick and approximately $0.08 \mathrm{~m}^{3}\left(0.1 \mathrm{yd}^{3}\right)$ of lead-contaminated soil were removed during investigation activities. After the lead-contaminated soil was removed, further sampling indicated that lead was not present above the PAL. No contamination remains at the site; therefore, no further action is required.

\subsubsection{Alternative 2 - Clean Closure}

The site-specific closure objectives for CASs at CAU 214 are presented in Table 2. Confirmation of closure objectives is discussed in Section 2.4, Confirmation of Corrective Actions. If the excavated volume of impacted soil at any site exceeds the original estimated volumes by 50 percent, the NNSA/NSO shall notify the NDEP. Waste disposal activities are discussed in Section 2.3, Waste Management.

\subsubsection{CAS 05-99-01, Fallout Shelters}

This site (Figure 8) is located in the Frenchman Flat Historic District in Area 5. The site consists of two collapsed fallout shelters $(6.1 \mathrm{~m}$ [20 ft] in diameter) and their adjacent instrument pits and dirt mounds. The two fallout shelters were built in 1957 to study the effects of nuclear blasts during Operation Plumbbob and have been identified as eligible for inclusion in the National Register of Historic Places. The shelter foundations, which are constructed of concrete and steel, 


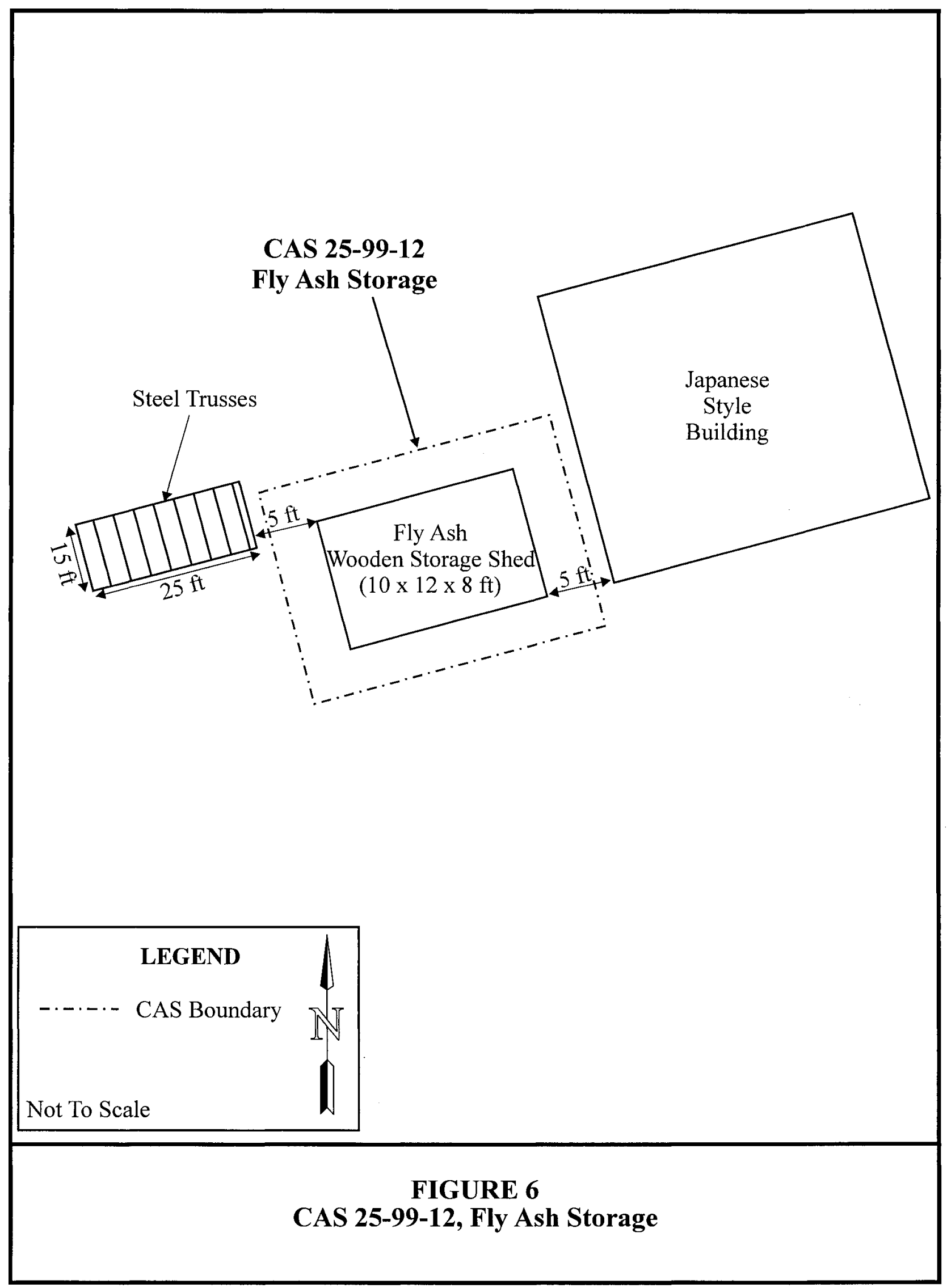




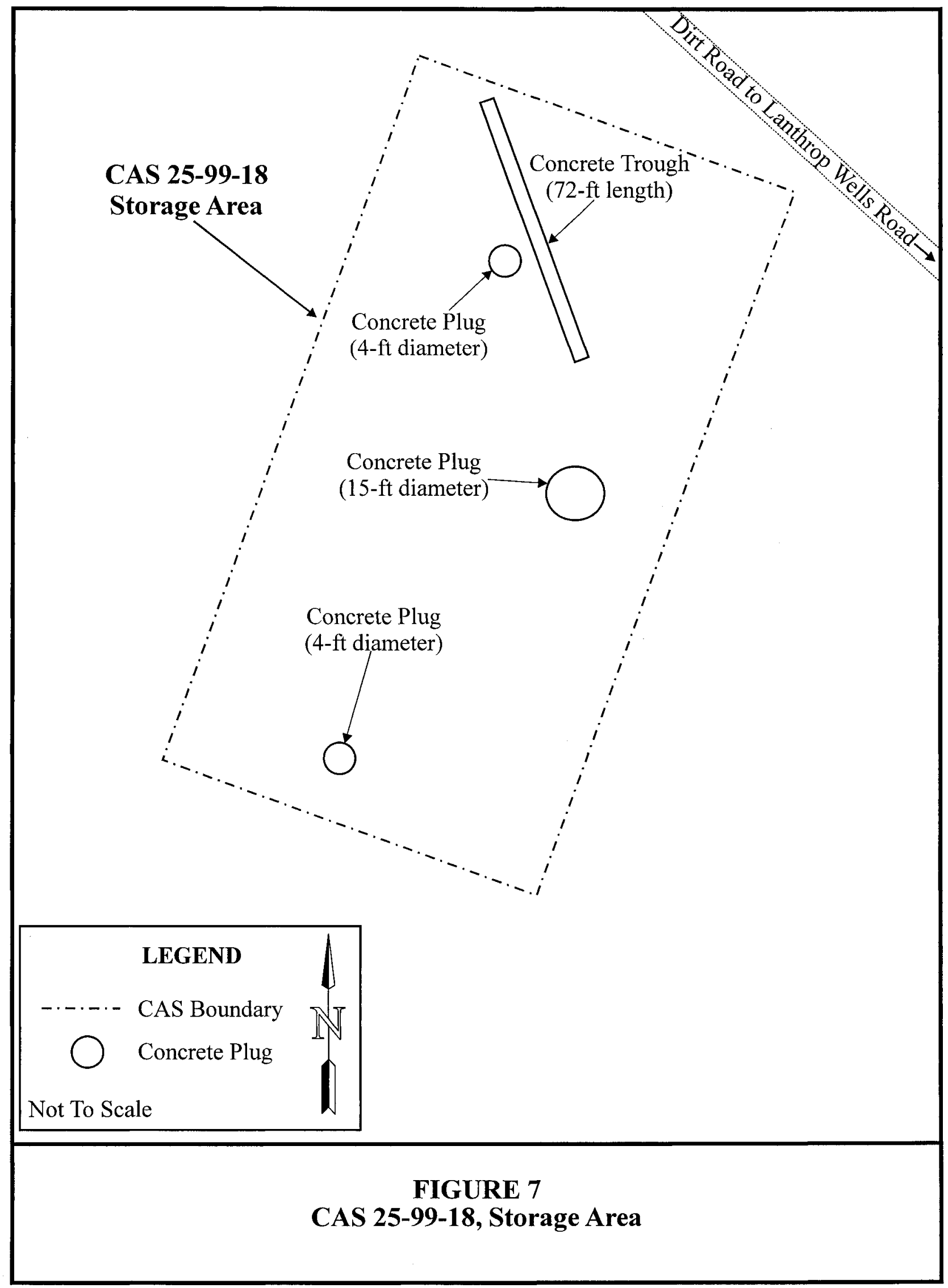




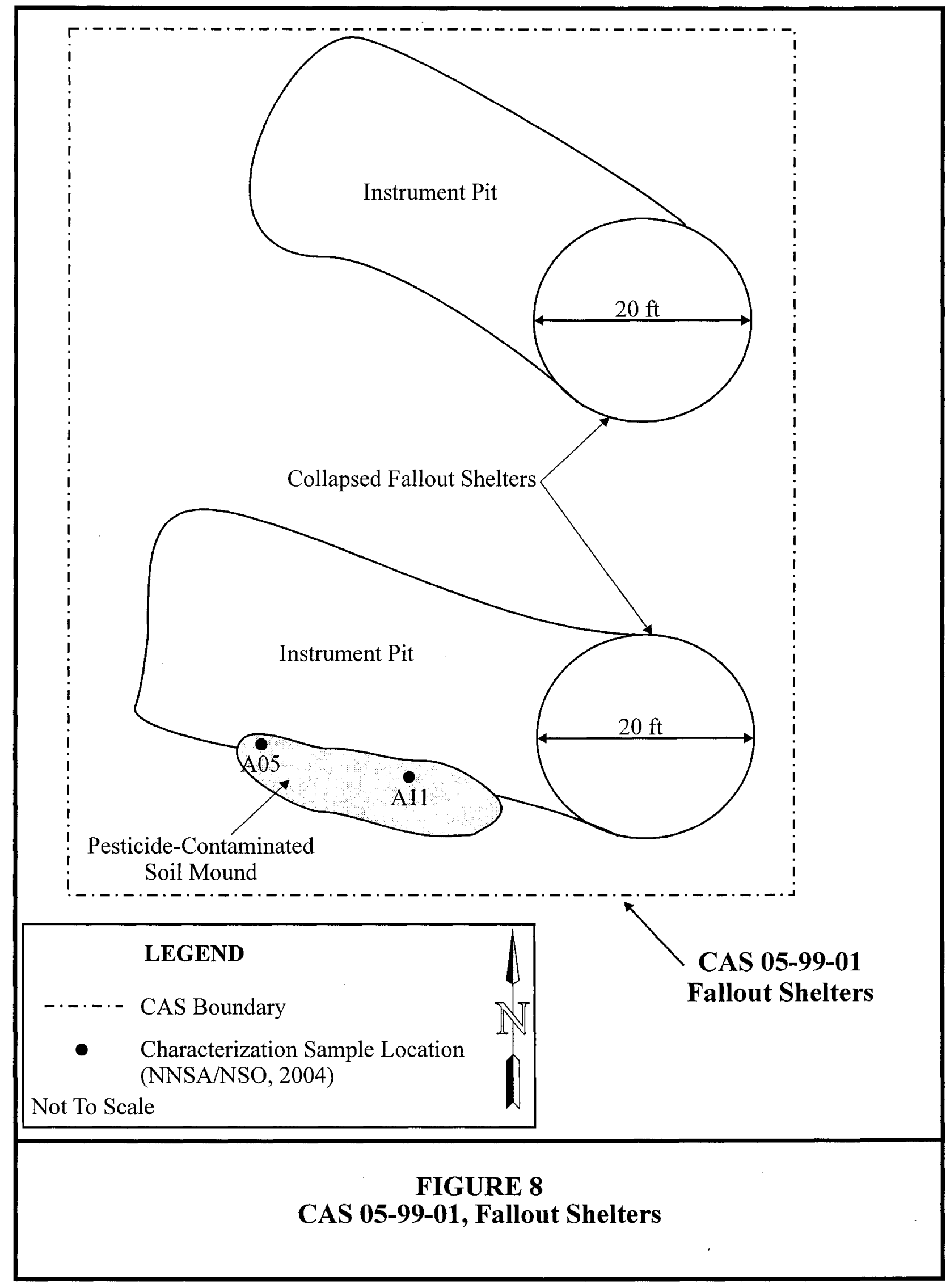


Table 2. Cleanup Criteria for CAU 214

\begin{tabular}{|c|c|c||}
\hline Contaminant of Concern & Cleanup Action Level & Reference \\
\hline \hline Chlordane & $6,500 \mu \mathrm{g} / \mathrm{kg}$ & EPA, 2002 \\
\hline Chromium & $450 \mathrm{mg} / \mathrm{kg}$ & EPA, 2002 \\
\hline Dieldrin & $110 \mu \mathrm{g} / \mathrm{kg}$ & EPA, 2002 \\
\hline Heptachlor & $380 \mu \mathrm{g} / \mathrm{kg}$ & EPA, 2002 \\
\hline TPH & $100 \mathrm{mg} / \mathrm{kg}$ & NAC, 2002 \\
\hline
\end{tabular}

Notes:

EPA: U.S. Environmental Protection Agency

$\mu \mathrm{g} / \mathrm{kg}$ : micrograms per kilogram

$\mathrm{mg} / \mathrm{kg}$ : milligrams per kilogram

NAC: Nevada Administrative Code

TPH: Total Petroleum Hydrocarbons

are still intact. The domes were coated with aluminum sheeting bonded to asbestos cloth and were severely damaged during tests. An excavated area adjacent to each shelter served as an instrument pit and provided access to shelter doors located below grade. The excavations are currently filled with tumbleweeds. Contamination due to radioactive fallout from nuclear weapons testing is not considered part of this CAS and will be addressed during the Soils Project as specified in the CAIP (NNSA/NSO, 2003).

The corrective action investigation indicated that the soil mound on the southern side of the southern most fallout shelter is contaminated with the pesticide dieldrin at concentrations exceeding its PAL of 110 micrograms per kilogram $(\mu \mathrm{g} / \mathrm{kg})$. Concentrations of dieldrin in the soil range from 200 to $1,600 \mu \mathrm{g} / \mathrm{kg}$. Approximately $60 \mathrm{~m}^{3}\left(79 \mathrm{yd}^{3}\right)$ of pesticide-contaminated soil is present to $0.6 \mathrm{~m}(2 \mathrm{ft})$ below the interface between the soil mound and the native soil. Although Europium-152 was identified in excess of the PAL in several soil samples, its primary source is weapons testing and will therefore not be considered a COC for this site. Radioactively contaminated soil surrounding the dieldrin-impacted soil mound will be addressed as part of the Soils Project (NNSA/NSO, 2004).

The source of the dieldrin is unknown. However, there is no indication that its presence is due to anything other than its intended purpose as a pesticide. Dieldrin is not listed as a Resource Conservation and Recovery Act (RCRA) hazardous waste (HW), and the soil does not exhibit any hazardous waste characteristics.

Closure activities will consist of excavation and disposal of approximately $60 \mathrm{~m}^{3}\left(79 \mathrm{yd}^{3}\right)$ of dieldrin-contaminated soil. A minimum of five verification samples will be collected from the excavation floor and side walls and analyzed for total pesticides. Additional samples may be collected if additional excavation is required. Upon verifying that the dieldrin-contaminated soil has been removed, the excavation will be backfilled with soil from an approved borrow source and contoured to the approximate surrounding grade. The excavated soil will be packaged into approved containers and randomly sampled for waste characterization prior to disposal. If radionuclides are present above onsite solid waste disposal limits, the waste will be managed as low-level waste (LLW) and disposed of appropriately. If no radionuclides or other contaminants 
that qualify as HW are identified in the waste characterization results, the dieldrin-contaminated soil can be disposed of as non-hazardous solid waste in the U10c landfill. If any other contaminants are identified, the soil will be handled and disposed of appropriately.

\subsubsection{Alternative 3 - Close in Place with Administrative Controls}

\subsubsection{CAS 25-23-01, Contaminated Materials, and CAS 25-23-19, Radioactive Material Storage}

These sites are located adjacent to each other west of the Yucca Mountain Project Sample Management Facility (YMP-SMF) in Area 25 (Figure 9). The sites were historically used as a storage yard for radioactively contaminated equipment, $\mathrm{HW}$, heavy equipment, reactor components, and drums and tanks containing unspecified material. Some of the materials stored in the yard were originally generated at Test Cell A and Test Cell C. In the mid-1990's, radiologically contaminated material was segregated into the northern portion of the storage yard in a posted and fenced radioactive materials area (RMA). This RMA was designated as CAS 25-23-19, and the remainder of the yard was designated as CAS 25-23-01. In 1995, solid waste, scrap metal, and equipment were taken to the Area 23 salvage yard, and approximately 20,000 pounds of radioactively contaminated material and equipment were taken to the Area 25 Radiological Material Storage Facility. No radioactively contaminated materials remain at these CASs.

Currently, wood, metal, and concrete debris are scattered throughout the CAS 25-23-01 storage area and the YMP-SMF yard, which is located directly east of the two CASs. A variety of metal containers with unknown contents, a large furnace, and assorted building materials are present. No equipment or debris is present within CAS 25-23-19. As a best management practice (BMP), items present within CAS 25-23-01 and the YMP-SMF yard that can be removed manually will be removed and disposed of appropriately. These items include wood crates, wood pallets, wood beams, miscellaneous wood debris, metal framing, metal beams, miscellaneous scrap metal, plywood, tires, an instrument rack, a dishwasher, and a mattress box spring. Table 3 lists the items that cannot be removed manually and will remain at the site. The locations of these items are shown in Figure 9. All items not listed in this table are to be removed and disposed of as construction debris.

Two stained areas in CAS 25-23-01 are contaminated with the pesticide chlordane above the PAL of $6,500 \mu \mathrm{g} / \mathrm{kg}$, and with the pesticide heptachlor above the PAL of $380 \mu \mathrm{g} / \mathrm{kg}$. Chlordane was found at concentrations ranging from $13,700 \mu \mathrm{g} / \mathrm{kg}$ to $2,700,000 \mu \mathrm{g} / \mathrm{kg}$, and heptachlor was found at concentrations ranging from $530 \mu \mathrm{g} / \mathrm{kg}$ to $140,000 \mu \mathrm{g} / \mathrm{kg}$. At one location (currently marked with a stake as sample location D07), approximately $70 \mathrm{~m}^{3}\left(92 \mathrm{yd}^{3}\right)$ of soil is contaminated with both pesticides to a depth of $1.1 \mathrm{~m}(3.5 \mathrm{ft})$ below ground surface (bgs). At the second location (currently marked with a stake as sample location D10), approximately $120 \mathrm{~m}^{3}\left(157 \mathrm{yd}^{3}\right)$ of soil is contaminated with both pesticides to a depth of $1.8 \mathrm{~m}(6.0 \mathrm{ft}) \mathrm{bgs}$. TPH-DRO is also present at high concentrations at these two locations (up to $3,500 \mathrm{mg} / \mathrm{kg}$ ). A third soil stain, located in the northwest corner of CAS 25-23-19 and green in appearance, is contaminated with chromium at concentrations up to $9,300 \mathrm{mg} / \mathrm{kg}$ to a depth of $1.2 \mathrm{~m}(4.0 \mathrm{ft})$ bgs. Approximately $80 \mathrm{~m}^{3}\left(105 \mathrm{yd}^{3}\right)$ of soil is contaminated above the PAL for chromium (NNSA/NSO, 2004). 


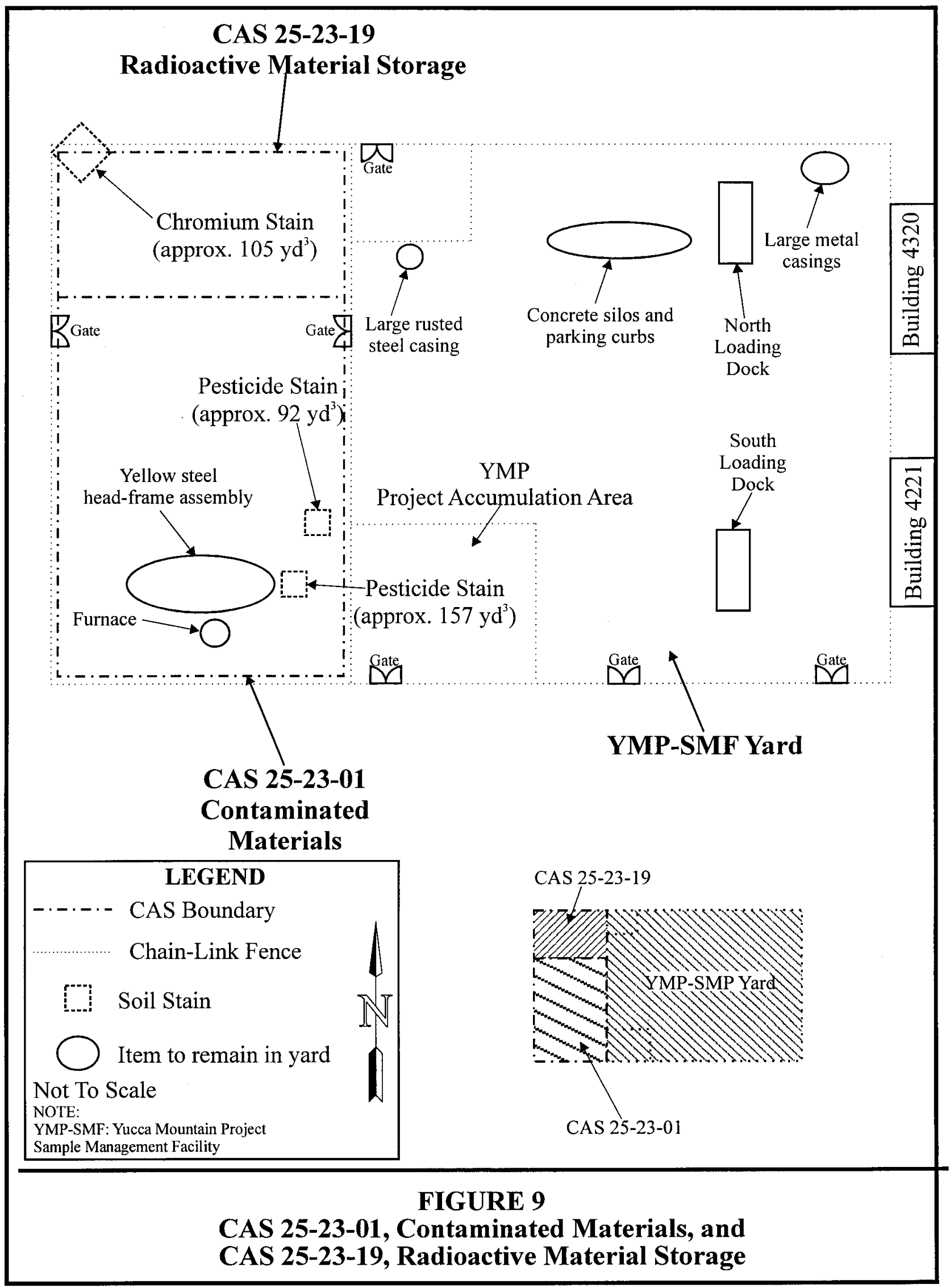


These three areas of soil contamination will be excavated, and the waste will be fully characterized and disposed appropriately. A minimum of five verification samples (one from each wall and one from the floor) will be collected from each of the three excavations and analyzed for total pesticides and total metals. When it is verified that all contamination due to pesticides and chromium has been removed, the areas will be backfilled with clean soil from the nearest approved borrow source and contoured to its surrounding grade.

In addition, TPH-DRO was identified at low concentrations (less than $580 \mathrm{mg} / \mathrm{kg}$ ) in surface soil throughout both CASs. The vertical extent of this contamination was determined to be less than $0.3 \mathrm{~m}(1 \mathrm{ft}) \mathrm{bgs}$. To reduce future health risks associated with the low concentrations of TPH contamination, administrative controls will be implemented. Use restriction signs will be posted on the existing chain link fence.

TABLE 3. ITEMS TO REMAIN AT CAS 25-23-01 AND THE YMP-SMF YARD

\begin{tabular}{|c|c|}
\hline Description of Item & Location of Item \\
\hline \hline Large rusted steel casing & Northwestern portion of YMP-SMF yard \\
\hline Concrete silos and parking curbs & Northern portion of YMP-SMF yard \\
\hline Large metal casings & Northwestern portion of YMP-SMF yard \\
\hline North loading dock & Northern portion of YMP-SMF yard \\
\hline South loading dock & Southern portion of YMP-SMF yard \\
\hline Yellow steel head-frame assembly & Southern portion of CAS 25-23-01 \\
\hline Furnace & Southern portion of CAS 25-23-01 \\
\hline
\end{tabular}

\subsection{CONSTRUCTION Quality ASSURANCE/Quality CONTROL}

Construction activities are limited to excavation and backfilling. No engineered structures will be constructed as part of site closure. Therefore, a construction Quality Assurance (QA) / Quality Control (QC) Plan is not required.

\subsubsection{Construction Field Sample Collection Activities}

Samples will be collected for the purpose of waste stream characterization and to verify that the site closure objectives have been met. All verification samples will be collected and analyzed according to Bechtel Nevada (BN) Environmental Restoration procedures. All field sample collection activities are addressed in Section 2.4, Confirmation of Corrective Actions.

\subsubsection{Construction Laboratory/Analytical Data Quality Indicators}

CAU 214 closure activities are limited to debris removal, site fencing and posting, and non-structural excavation and backfilling. Therefore, a QA/QC Plan is not required, and Construction Data Quality Indicators (DQIs) are not applicable. To ensure that backfill material remains consistent, all fill will be taken from an approved NTS borrow source. 


\subsection{Waste Management}

All waste will be stored, characterized, and disposed of according to state and federal regulations, the Resource Conservation and Recovery Act Part B Permit (NDEP, 2000), U.S. Department Of Energy (DOE) Orders, and BN procedures. Wastes generated during closure activities will be properly disposed of in onsite landfills or at offsite treatment, storage, and disposal (TSD) facilities. CAU 214 closure activities are expected to generate HW and sanitary waste/construction debris. LLW and/or mixed waste (MW) may be generated at CAS 05-99-01 (Fallout Shelters). Confirmation of waste disposal or transfer to BN Waste Generator Services for management and disposal will be included in the Closure Report (CR).

\section{Decontamination Fluids}

Equipment that becomes contaminated during closure activities will be decontaminated onsite. Dry decontamination will be the preferred method. For larger pieces of equipment that cannot be effectively decontaminated using dry decontamination techniques, wet decontamination techniques shall be used over a drum or waste pile. For equipment that cannot be decontaminated over a drum or soil waste pile, a decontamination pad, consisting of a lined, bermed area large enough to hold the heavy equipment, will be used. The equipment will be driven onto the pad and decontaminated using pressurized water. All rinsate will be solidified, characterized, properly classified, and disposed. Smaller equipment and/or tools may be decontaminated with soap and water.

\section{TPH Waste}

TPH is present in surface soil at CAS 25-23-01 (Contaminated Materials) and CAS 25-23-19 (Radioactive Material Storage). However, soil will only be removed from these sites due to pesticide or chromium contamination. The TPH that will be removed will be commingled in the soil with pesticides or chromium. The remaining TPH-contaminated soil will be closed in place at the site. All excavated soil at this site will be considered HW and disposed of appropriately.

\section{Hazardous Waste}

HW is anticipated to be generated during activities CAS 25-23-01 (Contaminated Materials) and CAS 25-23-19 (Radioactive Material Storage). Contaminated soil containing chromium or the pesticides heptachlor or chlordane will be excavated and handled as HW. No radionuclides are expected to be present exceeding background levels. HW also may be generated at CAS 05-99-01 (Fallout Shelters) pending waste characterization results. All HW will be managed and disposed of according to applicable BN procedures and state and federal regulations. Upon generation, all HW will be containerized and stored in a satellite accumulation area or a 90-Day HW Accumulation Area (EPA, 2003). After a waste profile is generated, the waste will be disposed of at an appropriate offsite TSD facility.

\section{Sanitary Waste/Construction Debris}

Sanitary waste (e.g., non-impacted personal protective equipment [PPE]) and construction debris (e.g., wood, concrete, metal) removed from sites will be randomly screened for free release (DOE/NV, 2000) and disposal. It will be disposed of in an onsite landfill (DOE/NV, 1997). 


\section{Low-Level Waste}

Date: March 2005

LLW may be generated at CAS 05-99-01 (Fallout Shelters). Closure activities at this site will include removal of soil contaminated with the pesticide dieldrin; however, Europium-152 contamination has been identified in this area and may be present in the excavated soil. All LLW will be characterized by laboratory analysis, and a profile for disposal will be prepared (NNSA/NV, 2003). Laboratory analysis of the waste will include gamma spectroscopy and isotopic analysis of plutonium, uranium, and strontium. All LLW will be stored in a RMA and packaged in approved containers. After approval of the waste profile, the LLW will be transported to an appropriate onsite disposal facility and disposed.

\section{Mixed Low-Level Waste}

Pending the waste characterization results, MW may be generated at CAS 05-99-01 (Fallout Shelters). Waste characterization will include analyses for radionuclides, Toxicity Characterization Leaching Procedure (TCLP) Volatile Organic Compounds, TCLP Semi-Volatile Organic Compounds, TCLP metals, Polychlorinated Biphenyls, and TPH. If radionuclides are present above onsite solid waste disposal limits and HW is determined to be in the removed soil, it will be managed and disposed of as MW. If required, the waste will be shipped to an offsite TSD facility for disposal.

\section{Personal Protective Equipment}

All PPE that becomes contaminated during closure activities shall be disposed of with the appropriate waste stream. All wastes generated during closure activities will be properly disposed of in onsite landfills or at a permitted offsite TSD facility.

\subsubsection{Waste Minimization}

All work activities that generate waste will follow the BN Waste Minimization and Pollution Prevention Program. Special care will be given to properly characterize and segregate the waste streams to avoid the generation of additional waste. Substantial waste reduction and cost savings are expected to result from these strategies.

\subsection{CONFIRMation Of CORRective ACtions}

Accurate and defensible analytical data will be collected to characterize waste and verify the closure objectives outlined in this CAP. All sampling activities will follow BN Organization Instruction (OI)-2152.108, "Soil Sampling" (BN, 2000b). Samples will be collected directly from the excavation locations indicated in the following sections, unless the excavation poses a safety hazard to sampling personnel. In this case, samples will be collected from the center of a backhoe bucket of soil collected from the indicated locations.

Samples collected for chemical and radiological analysis will be placed in appropriate containers, custody-sealed, screened for free release, and placed in sample coolers containing ice. All verification samples will be labeled with a unique sample identification number using the CAS number followed by the sample number (e.g., 059901-V1). Waste characterization samples will be identified by the CAS number followed by the sample number (e.g., 059901-WC1).

QA/QC samples will be collected and will include a blind duplicate labeled with a unique sample 
number and matrix spike/matrix spike duplicates, when appropriate. Trip blanks will be prepared and submitted when volatile organic compound samples are collected.

Sample collection date, time, and other pertinent information will be logged on a Chain of Custody form and in a bound project field notebook. Samples will be transferred to the BN Environmental Technical Services group following the procedures described in BN OI-2152.100, "Sampling Chain of Custody" (BN, 2000a). Samples will be analyzed by an offsite laboratory. Analytical results will be validated by $\mathrm{BN}$ personnel. Data determined not valid will be identified in the CR.

\subsubsection{No Further Action}

No closure activities have been identified for the following sites, and confirmation of any BMP activities will be achieved by visual inspection, field notes, and photographic documentation.

- CAS 11-22-03, Drum

- CASs 25-34-03, 25-34-04, and 25-34-05, Motor Dr/Gr Assembly (Bunker)

- CAS 25-99-12, Fly Ash Storage

- CAS 25-99-18, Storage Area

\subsubsection{Clean Closure}

\subsubsection{CAS 05-99-01, Fallout Shelters}

For this site, corrective actions include removal of pesticide-contaminated soil. Five verification samples, one from each wall and one from the floor of the excavation, will be collected and submitted for laboratory analysis for total pesticides. Because radioactive contamination is not considered part of this CAS, laboratory analysis for radionuclides will only be performed for waste characterization purposes and not for verification of closure. Additional soil will be excavated and additional verification samples collected if the sample results indicate the site closure objectives have not been met. Upon confirmation that the samples meet the site closure objectives, the site will be backfilled with clean soil.

\subsubsection{Closure in Place with Administrative Controls}

\subsubsection{CAS 25-23-01, Contaminated Materials, and CAS 25-23-19, Radioactive Material Storage}

For these sites, corrective actions include removal of soil at one location containing chromium and two locations containing pesticides. Five verification samples, one from each wall and one from the floor, will be collected from each excavation and submitted for laboratory analysis for either total metals or total pesticides, depending on the excavation sampled. Because TPH contaminated soil will be closed in place at this site, it is not necessary to analyze the verification samples for TPH. Additional soil will be excavated and additional verification samples collected if the verification sample results indicate the site closure objectives have not been met. Upon confirmation that the samples submitted for laboratory analysis meet the site closure objectives, the excavations will be backfilled with clean soil. 


\subsubsection{Laboratory/Analytical Data Quality Indicators}

Date: March 2005

Data Quality Objectives (DQOs) are qualitative and quantitative statements that specify the quality of the data required to support closure of a site. The DQOs for CAU 214 site investigations were defined in the CAIP (NNSA/NSO, 2003) using the Seven Step DQO Process developed by the U.S. Environmental Protection Agency (EPA, 2000).

All laboratory data generated during closure activities will be evaluated for data quality according to EPA Functional Guidelines (EPA, 1994a and 1994b) and the Industrial Sites Quality Assurance Project Plan (U.S. Department of Energy, National Nuclear Security Administration Nevada Operations Office [NNSA/NV], 2002). The data will be reviewed to ensure that all critical samples were appropriately collected and analyzed, and that the results passed data validation criteria. In addition, the final data packages will be validated using applicable BN operating instructions. These include OI-2151.303, "Validation of Radiological and Chemical Data" (BN, 2004), OI-2154.459, "Inorganic Data Verification and Validation" (BN, 2003a), and OI-2154.458, "Organic Data Verification and Validation" (BN, 2003b). More details on the proposed number and location of the verification samples are given in Sections 2.4.2, Clean Closure, and 2.4.3, Closure in Place with Administrative Controls.

DQIs are qualitative and quantitative statements that specify the data requirements of a project. The DQIs include accuracy, comparability, completeness, precision, representativeness, and sensitivity. These DQIs are discussed in the following sections.

\subsubsection{Accuracy}

Accuracy measures the degree of difference between measured or calculated values of a parameter and the true value of that parameter. The closer the measurement is to the true value, the more accurate the measurement. Accuracy will be assessed by examining the percent recovery of laboratory control and spiked samples. A percent recovery within the range of $70-130$ percent indicates satisfactory analytical accuracy (NNSA/NV, 2002).

\subsubsection{Comparability}

Comparability is a qualitative measure that expresses the confidence that one data set can be compared to another. It will be achieved by adhering to the standardized field sampling procedures. The same analytical laboratory will perform the same analyses for all samples. All samples will be collected using BN standard methods of sample collection (BN, 2000b). Sample results will be reported in standard units to allow for comparison of the data.

\subsubsection{Completeness}

Completeness is a quantitative measure of data quality expressed as the percentage of valid data obtained that satisfies the project-specific requirements. Since a limited number of samples will be collected for both waste characterization and verification of closure, 100 percent of the data collected must be of acceptable quality to maintain acceptable QA/QC standards. 


\subsubsection{Precision}

Precision measures the reproducibility of data under a given set of conditions. It is a quantitative measurement of the variability of a population of measurements compared to their average value and applies to parameters sampled and analyzed in duplicate. Precision will be assessed by collecting one duplicate sample for every 20 regular samples. Duplicate samples will be collected and analyzed for each medium and analyte. The precision of the analytical results will be assessed by calculating the Relative Percent Difference (RPD) for a sample and its duplicate sample results. A RPD of less than or equal to 30 percent indicates acceptable precision (NNSA/NV, 2002).

\subsubsection{Representativeness}

Representativeness is a qualitative measure of the degree to which the sample data accurately and precisely represents a characteristic of a sample population or environmental condition. This DQI will be attained by ensuring that the sample locations, analytical parameters, analytical methods, sampling protocols, and sample handling all meet the project-specific objectives.

\subsubsection{Sensitivity}

Sensitivity is the capability of a method or instrument to discriminate between measurements representing different levels of a variable of interest. It is determined from the standard deviation at the concentration level of interest and represents the minimum difference of concentration that can be distinguished between two samples with a high degree of confidence. Sensitivity must be sufficient to detect contaminants at or below decision levels and will be achieved by analyzing all samples using the appropriate offsite laboratories, methods, and instruments.

\subsection{PERMITS}

Prior to beginning closure activities, planning documents and permits will be prepared, including a National Environmental Policy Act (NEPA) Checklist, NNSA/NSO Real Estate/Operations Permit (REOP), Radiological Work Permit (RWP), utility clearance, and excavation permit.

\subsubsection{National Environmental Policy Act Checklist}

A NEPA Checklist will be completed prior to all excavation activities at the site. Excavation activities will follow all applicable federal, state, and local laws; regulations; and permits regarding protection of the environment.

\subsubsection{NNSA/NSO Real Estate/Operations Permit}

A REOP will be obtained prior to beginning closure activities. The permit will establish the NNSA/NSO as the prime authority possessing control of the site. The REOP will establish a sole governing organization responsible for safety and will identify the NNSA/NSO's responsibility to plan and schedule activities.

\subsubsection{Radiological Work Permit}

RWPs will be required for work at any radiologically impacted site when radiological conditions require, as determined by BN Health Physics. RWPs inform workers of the specific PPE necessary to protect them while performing work and identify site-specific controls. Personnel working in a 
radiologically controlled Contamination Area will be required to read the applicable RWP(s) and acknowledge their understanding of the requirements before entry into the Contamination Area. The RWP(s) will be maintained by a radiological control technician at the entrance to the Contamination Area. All site workers will be required to be Radiation Worker II trained to perform any work within a radiologically controlled area.

\subsubsection{Utility Clearances and Excavation Permits}

A utility clearance will be performed and an Excavation-Penetration Permit will be obtained prior to beginning any excavation or penetration activities. A copy of the permit will be kept onsite throughout the duration of the project. 
CAP - CAU 214

Section: Detailed SOW

Revision: 0

Date: March 2005

\section{THIS PAGE INTENTIONALLY LEFT BLANK}




\subsection{SCHEDULE}

Field activities will be initiated in Fiscal Year (FY) 2006. Field preparation activities are tentatively targeted for the second quarter of FY 2006, and field work is tentatively targeted for the third quarter of FY 2006. Sufficient flexibility has been incorporated into the field schedule to allow for minor delays due to inclement weather, equipment failure, etc. The NNSANSO shall notify the NDEP of any condition or event that may impact the project schedule. 
CAP - CAU 214

Section: Schedule

Revision: 0

Date: March 2005

\section{THIS PAGE INTENTIONALLY LEFT BLANK}




\subsection{POST-CLOSURE PLAN}

Corrective Action Alternative 3, Closure in Place with Administrative Controls, requires post-closure inspections. The closure alternative includes implementing use restrictions to prohibit unauthorized intrusive activities at CAS 25-23-01 (Contaminated Materials) and CAS 25-23-19 (Radioactive Material Storage).

\subsection{INSPECTIONS}

Annual site inspections will be conducted at CAS 25-23-01 (Contaminated Materials) and CAS 25-23-19 (Radioactive Material Storage). Inspections will verify that the proper warning signs are in place and readable and that use restrictions are being maintained. The results of the inspection will be documented in a single annual letter report. The letter report will include inspection checklists, field notes, and a discussion of observations and will provide a record of maintenance activities, if required. The inspection report will be incorporated into the combined annual letter report and submitted to the NDEP.

\subsection{MONITORING}

As no sampling or collection of data will be performed after closure of CAU 214, no post-closure monitoring is required at any CAS in CAU 214. However, post-closure visual inspections will be performed for the CASs identified in Section 4.1, Inspections.

\subsection{MAINTENANCE ANd REPaIR}

If any maintenance and repair requirements are identified during the annual inspection of any CAS, the NDEP will be notified, funding will be requested, and the repairs scheduled. Any repair or maintenance performed at these CASs shall be documented in writing at the time of the repair and included in the annual letter report. 
CAP - CAU 214

Section: Post-Closure Plan

Revision: 0

Date: March 2005

THIS PAGE INTENTIONALLY LEFT BLANK 


\subsection{REFERENCES}

BN, see Bechtel Nevada.

Bechtel Nevada. 2000a. "Sampling Chain of Custody," Organization Instruction OI-2152.100. Las Vegas, Nevada.

Bechtel Nevada. 2000b. "Soil Sampling", Organization Instruction OI-2152.108. Las Vegas, Nevada.

Bechtel Nevada. 2003a. "Inorganic Data Verification and Validation, Revision 1", OI-2154.459. Las Vegas, Nevada.

Bechtel Nevada. 2003b. "Organic Data Verification and Validation", OI-2154.458. Las Vegas, Nevada.

Bechtel Nevada. 2004. "Validation of Radiological and Chemical Data, Revision 3," OI-2151.303. Las Vegas, Nevada.

DOE/NV, see U.S. Department of Energy, Nevada Operations Office.

EPA, see U.S. Environmental Protection Agency.

FFACO, see Federal Facility Agreement and Consent Order.

Federal Facility Agreement and Consent Order. 1996 (as amended). Agreed to by the State of Nevada, U.S. Department of Energy, and U.S. Department of Defense.

NAC, see Nevada Administrative Code.

NDEP, see Nevada Division of Environmental Protection.

NNSA/NSO, see U.S. Department of Energy, National Nuclear Security Administration Nevada Site Office.

NNSA/NV, see U.S. Department of Energy, National Nuclear Security Administration Nevada Operations Office.

Nevada Administrative Code. 2002. NAC 445A.2272, Contamination of Soil: Establishment of Action Levels. Carson City, Nevada.

Nevada Division of Environmental Protection. 2000. Nevada Division of Environmental Protection Permit for a Hazardous Waste Management Facility, Permit Number NEV HW009, Carson City, NV. 


\section{REFERENCES (continued)}

U.S. Department of Energy, National Nuclear Security Administration Nevada Operations Office. 2002. Industrial Sites Quality Assurance Project Plan. DOE/NV--372--REV 3. Las Vegas, Nevada.

U.S. Department of Energy, National Nuclear Security Administration Nevada Operations Office. 2003. Nevada Test Site Waste Acceptance Criteria, Revision 5. DOE/NV-325-REV 5. Las Vegas, NV.

U.S. Department of Energy, National Nuclear Security Administration Nevada Site Office. 2003. Corrective Action Investigation Plan for Corrective Action Unit 214: Bunker and Storage Areas, Nevada Test Site, Nevada. DOE/NV--893. Las Vegas, NV.

U.S. Department of Energy, National Nuclear Security Administration Nevada Site Office. 2004. Corrective Action Decision Document for Corrective Action Unit 214: Bunker and Storage Areas, Nevada Test Site, Nevada. DOE/NV--956. Las Vegas, NV.

U.S. Department of Energy, Nevada Operations Office. 1997. Permit for Area 9 U10c Disposal Site Class III Industrial Solid Waste Disposal Site, Permit SW/13/097/03 (revised June 2000), Las Vegas, NV.

U.S. Department of Energy, Nevada Operation Office. 2000. NV/YMP Radiological Control Manual, Revision 4. DOE/NV/11718-079, Rev. 4. Las Vegas, NV.

U.S. Environmental Protection Agency. 1994a. Laboratory Data Validation Functional Guidelines for Evaluating Inorganic Analyses, EPA/540/R-94/083. Washington, D.C.

U.S. Environmental Protection Agency. 1994b. Laboratory Data Validation Functional Guidelines for Evaluating Organic Analyses, EPA/540/R-94/082. Washington, D.C.

U.S. Environmental Protection Agency. 2000. Guidance for Data Quality Objectives Process, EPA AQ/G-4, EPA/600/R-96/055. Washington D.C.

U.S. Environmental Protection Agency. 2002. Region IX Preliminary Remediation Goals (PRGs). San Francisco, CA.

U.S. Environmental Protection Agency. 2003. Title 40, Code of Federal Regulations, 264.175, Hazardous Waste Containment. Washington, D.C. 


\section{APPENDIX A.1}

\section{ENGINEERING SPECIFICATIONS AND DRAWINGS}

*Engineering specifications and drawings are not required for closure of Corrective Action Unit 214. This Appendix is included here as required by the standard Federal Facility Agreement and Consent Order outline for a Corrective Action Plan. 
CAP - CAU 214

Section: Appendix A.I

Revision: 0

Date: March 2005

THIS PAGE INTENTIONALLY LEFT BLANK 


\section{APPENDIX A.2}

\section{SAMPLING AND ANALYSIS PLAN*}

* Sufficient detail on the type, number, and location of verification samples to be collected to verify site closure activities has been provided in Section 2.4.2, Confirmation of Corrective Actions. Waste characterization sampling activities are described within Section 2.3, Waste Management. This Appendix is included here as required by the standard Federal Facility Agreement and Consent Order outline for a Corrective Action Plan. 
Section: Appendix A.2

Revision: 0

Date: March 2005

THIS PAGE INTENTIONALLY LEFT BLANK 
APPENDIX A.3

\section{PROJECT ORGANIZATION}


CAP - CAU 214

Section: Appendix A.3

Revision: 0

Date: March 2005

\section{THIS PAGE INTENTIONALLY LEFT BLANK}




\section{PROJECT ORGANIZATION}

The U.S. Department of Energy, National Nuclear Security Administration Nevada Site Office (NNSA/NSO) Project Manager or Task Manager will serve as the primary point of contact for all activities conducted for this project. The NNSA/NSO Project Manager is responsible for seeing that all activities conducted during the project fulfill the obligations of NNSA/NSO, as described in the Federal Facility Agreement and Consent Order of 1996 (as amended) and the Nevada Division of Environmental Protection (NDEP) approved work plan. The NNSA/NSO Project Manager will plan, authorize, and control project work so that activities are completed according to the work plan on schedule and within the budget. The NNSA/NSO Project Manager will be the primary point of contact with the NDEP. The NNSA/NSO points of contact for this project are as follows:

NNSA/NSO Acting Project Manager: Sabine Curtis

Telephone Number: (702) 295-0542

NNSA/NSO Task Manager: Kevin Cabble

Telephone Number: (702) 295-5000

The identification of the project Health and Safety Officer and the Quality Assurance Officer can be found in the appropriate plan. However, personnel are subject to change and it is suggested that the appropriate U.S. Department of Energy Project Manager be contacted for further information. The Task Manager will be identified in the FFACO Monthly Activity Report prior to the start of field activities. 
Date: March 2005

THIS PAGE INTENTIONALLY LEFT BLANK 
CAP - CAU 214

Section: Library Distribution List

Revision: 0

Date: March 2005

\section{LIBRARY DISTRIBUTION LIST}


CAP - CAU 214

Section: Library Distribution List

Revision: 0

Date: March 2005

THIS PAGE INTENTIONALLY LEFT BLANK 
U.S. Department of Energy

National Nuclear Security Administration

Nevada Site Office

Technical Library

P.O. Box $98518, \mathrm{M} / \mathrm{S} 505$

Las Vegas, NV 89193-8518

U.S. Department of Energy

Office of Scientific and Technical Information

P.O. Box 62

Oak Ridge, TN 37831-0062

Southern Nevada Public Reading Facility

c/o Nuclear Testing Archive

P.O. Box 98521, M/S 400

Las Vegas, NV 89193-8521

Manager, Northern Nevada FFACO

Public Reading Facility

c/o Nevada State Library \& Archives

Carson City, NV 89701-4285
1 (Uncontrolled)

1 (Uncontrolled, electronic copy)

2 (Uncontrolled, electronic copies)

1 (Uncontrolled, electronic copy) 
CAP - CAU 214

Section: Library Distribution List

Revision: 0

Date: March 2005

THIS PAGE INTENTIONALLY LEFT BLANK 